\title{
HUBUNGAN JARAK MONITOR, DURASI PENGGUNAAN KOMPUTER, TAMPILAN LAYAR MONITOR, DAN PENCAHAYAAN DENGAN KELUHAN KELELAHAN MATA
}

\author{
RELATION AMONG DISTANCE MONITOR, DURATION OF COMPUTER \\ USE, SCREEN DISPLAY MONITOR AND LIGHTING WITH COMPLAINTS OF \\ EYE FATIGUE
}

\author{
Dessy Widhya Putri, Mulyono \\ Departemen Keselamatan dan Kesehatan Kerja \\ Fakultas Kesehatan Masyarakat, Universitas Airlangga \\ Email: dessywidhya112@gmail.com
}

\begin{abstract}
The use of the computer was very support various human activities. Although many of the benefits gained from computer but if we weren't awareness can cause health problem, such as complaints of eye fatigue. The purpose of this research was to find the relation between distance monitor, duration of computer use, screen display monitor and lighting with complaints of eye fatigue on workers at PT. Indonesia Power UP Semarang. This research was a quantitative research with cross sectional design. Population in this research was all of workers at PT Indonesia Power UP Semarang as many as 280 peoples. Samples was taken by purposive sampling method with some defined criterias until gained 77 people. The instruments used in this research were questionnaires, meter, and lux meter. Univariate analysis performed using the proportion to clarify the prevalence of subjective complaints of eye fatigue and factors related to complaints of eye fatigue, while the bivariate analysis performed by chi-square test $\left(X^{2}\right)$ with a significant level of 5\%. Result showed that $80.5 \%$ had subjective complaints of eye fatigue. Chi square test result were p-value of monitor distance variable was 0.499 , p-value of screen display monitor variable was 0.016 , p-value of duration of computer use variable was 0.018 and p-value of lighting variable was 1.000. The conclusion of this research was from the four variables only two which related significantly with complaints of eye fatigue on workers PT. Indonesia Power UP Semarang were duration of computer use and screen display monitor.
\end{abstract}

Keywords: complaints of eye fatigue, computer users, duration of computer use

\begin{abstract}
ABSTRAK
Penggunaan komputer sangatlah menunjang berbagai macam aktivitas pekerjaan manusia. Walaupun banyak manfaat yang diperoleh dari komputer namun masih belum banyak yang menyadari bahwa penggunaan komputer juga dapat menyebabkan masalah kesehatan, salah satunya keluhan kelelahan mata. Tujuan dari penelitian ini adalah mengetahui hubungan jarak monitor, durasi penggunaan komputer, tampilan layar komputer dan pencahayaan dengan keluhan kelelahan mata pada pekerja PT. Indonesia Power UP Semarang. Penelitian ini adalah penelitian kuantitatif dengan rancang bangun cross sectional. Teknik pengambilan sampel menggunakan purposive sampling. Populasi dalam penelitian ini adalah seluruh pekerja PT. Indonesia Power UP Semarang sebanyak 280 pekerja. Sampel dalam penelitian ini adalah 77 pekerja yang memenuhi kriteria inklusi dan kriteria eksklusi. Instrumen yang digunakan berupa kuesioner, meteran, dan luxmeter. Analisis univariat dilakukan menggunakan nilai proporsi untuk menjelaskan gambaran keluhan kelelahan mata dan faktor-faktor yang berhubungan dengan keluhan kelelahan mata, sedangkan analisis bivariat dilakukan dengan uji chi-square $\left(\mathrm{X}^{2}\right)$ dengan tingkat kemaknaan 5\%. Hasil penelitian menunjukkan variabel jarak monitor memiliki p-value $0,499(\mathrm{p}>\alpha)$, variabel tampilan monitor memiliki $p$-value sebesar $0,016(\mathrm{p}<\alpha)$, variabel durasi penggunaan komputer memiliki $p$-value $0,018(\mathrm{p}<\alpha)$ dan variabel pencahayaan memiliki $p$-value $=1,000(\mathrm{p}>\alpha)$. Kesimpulan yang dapat ditarik adalah bahwa hanya variabel tampilan monitor dan durasi penggunaan komputer yang berhubungan dengan keluhan kelelahan mata pada pengguna komputer.
\end{abstract}

Kata kunci: durasi penggunaan komputer, keluhan kelelahan mata, pengguna komputer,

(C2018 IJOSH. Open access under CC BY NC-SA license doi: 10.20473/ijosh.v7i1.2018.1-10. Received 4

June 2017, received in revised form 12 July 2017, Accepted 5 August 2017, Published: 2 January 2018 


\section{PENDAHULUAN}

Perkembangan teknologi dewasa ini telah melaju dengan pesat, hal ini diimbangi dengan semakin membawa keuntungan bagi manusia yaitu pekerjaan manusia lebih dimudahkan. Salah satu teknologi yang digunakan manusia yaitu komputer. Penggunaan komputer di tempat kerja semakin meningkat seiring karena memberi keefektifan pada tenaga dan waktu. Keuntungan yang dapat kita peroleh dalam penggunaan komputer yaitu pekerjaan akan cepat terselesaikan dan hasilnya akan lebih maksimal karena komputer mempunyai kecepatan dan ketelitian yang tinggi dalam mengerjakan fungsinya. Komputer mempunyai media penyimpanan data berkapasitas besar yang ringkas dan mampu mengolah data dalam jumlah yang besar.

Telah banyak manfaat yang telah ditawarkan oleh komputer kepada manusia, komputer juga dapat menjadi ancaman bagi manusia. Salah satunya yaitu manusia semakin bergantung terhadap bantuan komputer dan berkurangnya tenaga kerja manusia akibat pekerjaannya digantikan dengan komputer. Ketergantungan seseorang dalam penggunaan komputer dalam jangka waktu yang lama akan mempengaruhi kesehatan manusia, terutama kesehatan mata. Gangguan kesehatan yang disebabkan oleh penggunaan komputer diantaranya computer vision syndrome (CVS), dan repetitive strain injury (RSI). CVS adalah kelelahan mata yang dapat mengakibatkan penglihatan ganda, penglihatan ganda, sakit kepala, sakit punggung, penglihatan menjadi silau terhadap cahaya dan berbagai masalah lainnya. RSI adalah istilah yang digunakan untuk mendefinisikan cedera pada otot dan saraf akibat aktivitas yang berulang-ulang seperti mengklik mouse dan mengetik data atau naskah.

Menurut Santoso (2011) sekitar 60.000.000 manusia mengalami gangguan mata dan jumlahnya meningkat 1.000 .000 setiap tahunnya. Orang yang menderita gangguan mata ini sebagian besar memiliki pekerjaan yang membuat dia sering berinteraksi dengan komputer. Penyebab keluhan kelelahan mata sering terjadi karena proyeksi gambar pada mata secara terus menerus dengan frekuensi cepat (refresh rate). Mata manusia sebenarnya didesain untuk melihat benda yang berbentuk tiga dimensi akan tetapi ketika mata dipergunakan untuk melihat gambar pada monitor komputer yang tergolong dua dimensi, maka mata akan dipaksa untuk menerjemahkan objek dua dimensi ke objek tiga dimensi (Santoso, 2011).

Penyebab keluhan kelelahan mata saat penggunaan komputer lainnya yaitu jarak mata saat penggunaan komputer dengan layar monitor terlalu dekat. Hasil penelitian yang dilakukan oleh lembaga survey American Optometric Association (AOA) pada tahun 2004 diketahui bahwa tidak jarang pekerja kantor mengeluhkan kelelahan mata karena terlalu lama di depan komputer dan radiasi gelombang elektromagnetik yang dihasilkan oleh layar monitor. Selain masalah gangguan visual yang muncul akibat dari penggunaan komputer yang terlalu lama, pengguna komputer juga akan merasakan gangguan sakit kepala, sakit leher dan sakit bahu. Menurut Ariyanti (2006), seseorang akan cenderung jarang mengedipkan mata ketika bekerja di depan komputer yang sedang menyala. Padahal kedipan mata sangatlah bermanfaat untuk mengurangi risiko mata mengalami kekeringan. Semakin lama mata terbuka, mata akan menjadi panas dan berkemungkinan kornea mata mengalami dehidrasi, serta mata terasa berat seperti pasir di kelopak matanya (Ariyanti, 2006).

Menurut Ariyanti (2006) penerangan yang kurang di tempat kerja bisa menyebabkan keluhan kelelahan mata (Astenophia) dan begitu juga sebaliknya, apabila penerangan berlebihan sehingga menimbulkan kesilauan mata juga dapat menyebabkan mata mudah lelah. Oleh karena itu, diperlukan penerangan yang cukup memadai untuk mengurangi terjadinya keluhan kelelahan mata. Menurut Budiono dkk (2008), ketika seseorang bekerja di depan komputer dengan pencahayaan kurang dari 300 lux, maka ia memiliki risiko mengalami keluhan kelelahan mata sebesar 10,7 kali lebih besar dibandingkan dengan seorang pekerja pengguna komputer dengan pencahayaan sama atau lebih dari 300 lux.

Apabila sebuah pekerjaan dengan ketelitian yang tinggi tidak diimbangi dengan pencahayaan yang memadai akan berujung pada kondisi mata yang lebih cepat mengalami kelelahan. Keluhan kelelahan mata terjadi akibat kelelahan pada otot mata dan saraf mata akibat dari mata yang tegang secara terus menerus. Keluhan kelelahan mata ini tidak bersifat permanen, namun dapat mengganggu produktivitas kerja seperti meningkatnya frekuensi kesalahan saat bekerja, mengganggu konsentrasi, menambah beban kerja, kehilangan jam kerja, dan menurunkan produktivitas kerja karyawan (Pheasant, 2005). 
Hasil survey yang dilakukan oleh AOA tahun 2004 dipaparkan bahwa beberapa faktor yang mendukung terjadinya kejadian keluhan kelelahan mata yaitu karakteristik atau jenis komputer dan adanya pembiasan pada mata atau sering disebut juga kelainan refraksi pada mata pengguna komputer. Menurut Pheasant (2005) beberapa hal yang mempengaruhi seseorang untuk dapat melihat suatu objek di lingkungan kerjanya yaitu jarak melihat objek kerja, lama penggunaan komputer, tingkat pencahayaan, ukuran objek kerja, bentuk objek kerja dan kekontrasan layar monitor. Menurut Santoso (2009), beberapa faktor yang berpengaruh terhadap keluhan kelelahan mata diantaranya intensitas pencahayaan ruangan, suhu ringan, kelembaban ruangan, dan istirahat mata. Guyton dan Hall (2014) memaparkan bahwa usia pekerja juga berpengaruh terhadap kecepatan timbulnya kelelahan mata. Menurut Suma'mur (2013), usia memiliki pengaruh terhadap keluhan kelelahan mata karena bertambahnya usia biasanya diimbangi dengan berkurangnya ketajaman penglihatan mata, terutama pada seseorang yang berusia 40 tahun atau lebih.

Penelitian tentang kelelahan maya di PT. Indonesia Power Unit Pembangkitan (UP) Semarang sebelumnya telah dilakukan oleh Supriati (2012), namun subjek sampel dari penelitian beliau hanya dibatasi pada karyawan bagian administrasi, berbeda dengan penelitian kami yang subjek penelitiannya diperoleh dari berbagai lintas bidang pekerjaan di PT. Indonesia Power UP Semarang. Penelitian Supriati (2012) menunjukkan diperoleh informasi bahwa sebanyak $86,4 \%$ pekerja administrasi yang merasakan kelelahan mata, sedangkan sisanya tidak merasakan kelelahan mata. Dalam penelitian tersebut menampakkan bahwa terdapat hubungan negatif antara intensitas pencahayaan dengan kelelahan mata. Semakin tinggi intensitas pencahayaan maka waktu reaksi mata terhadap rangsangan cahaya akan semakin rendah.

Banyak dilakukan penelitian terdahulu terkait dengan kelelahan mata, namun masalah kesehatan dalam penggunaan komputer belum menjadi pusat perhatian yang intensif pada masyarakat. Sehingga banyak orang yang enggan menghiraukannya dampak kesehatan ini karena menurutnya imbas dari dampak terhadap kesehatan jarang dirasakan oleh secara langsung dalam kurun waktu singkat. Akan tetapi dalam kurun waktu tertentu masalah kesehatan ini akan menjadi masalah yang serius apabila kesadaran terhadap kesehatan sejak dini tidak segera dibangun.

\section{METODE}

Melihat dari sifatnya, penelitian ini merupakan penelitian deskriptif karena penelitian ini bertujuan untuk menemukan fakta dan menggambarkan keseluruhan mulai dari kegiatan penelitian hingga hasil penelitian dan menganalisis data yang telah diperoleh secara objektif. Berdasarkan tempatnya, penelitian ini termasuk kedalam penelitian lapangan karena pengamatan variabelnya dilakukan secara langsung di tempat kerja (lapangan). Rancang bangun yang digunakan dalam penelitian ini adalah cross sectional. Populasi penelitian ini sebesar 280 pekerja, mereka adalah seluruh karyawan PT. Indonesia Power Unit Pembangkitan (UP) Semarang. Besar Sampel pada penelitian ini sebanyak 77 pekerja PT. Indonesia Power UP Semarang.

Teknik yang digunakan untuk menentukan jumlah sampel yang diadopsi dalam penelitian ini yaitu teknik purposive sampling. Teknik purposive sampling adalah teknik dalam pengambilan sampel penelitian dengan pertimbangan tertentu dari peneliti. Pertimbangan tersebut didasarkan pada dua kriteria inklusi dan eksklusi yang telah ditetapkan oleh peneliti. Kriteria inklusi penelitian ini adalah karyawan tetap PT. Indonesia Power UP Semarang yang bekerja menggunakan komputer dan bersedia menjadi responden penelitian. Kriteria eksklusi dalam penelitian ini yaitu karyawan yang sedang tidak hadir saat penelitian dilakukan dan pekerja yang menolak berpartisipasi untuk menjadi responden penelitian ini.

Penelitian ini dilakukan pada September 2016. Lokasi penelitian ini yaitu PT. Indonesia Power UP Semarang yang beralamatkan Jalan Ronggowarsito, Kompleks Pelabuhan Tanjung Mas, Semarang, Jawa Tengah. Data primer dalam penelitian ini dikumpulkan dengan menyebarkan kuesioner kepada responden dan melakukan pengukuran jarak mata responden dengan komputer menggunakan mistar serta dilakukan pengukuran pencahayaan menggunakan luxmeter. Data sekunder dalam penelitian ini adalah profil perusahaan PT. Indonesia Power UP Semarang.

Variabel dalam penelitian ini ada empat yaitu jarak monitor, tampilan layar monitor, durasi penggunaan komputer, dan pencahayaan. Ada dua 
macam analisis yang diterapkan dalam penelitian ini, yaitu analisis univariat dan analisis bivariat. Analisis univariat dilakukan dengan menampilkan distribusi frekuensi dari masing-masing variabel. Sedangkan analisis bivariat digunakan guna untuk mengetahui hubungan antara variabel jarak monitor, tampilan layar monitor, durasi penggunaan komputer dan pencahayaan dengan keluhan kelelahan mata menggunakan uji chi-square $\left(\mathrm{X}^{2}\right)$ dengan tingkat kemaknaan $5 \%$.

\section{HASIL}

\section{Gambaran Umum Responden}

Berdasarkan kriteria inklusi dan eksklusi diperoleh responden sebesar 77 orang. Beragam usia responden, mulai dari responden dengan usia di bawah 40 tahun yang sebesar 26 orang $(33,8 \%)$, hingga berusia 40 tahun keatas sebesar 51 orang $(66,2 \%)$. Jenis kelamin responden terbagi menjadi laki-laki sebesar 49 orang $(63,6 \%)$ dan perempuan sebesar 28 orang $(36,4 \%)$. Masa kerja responden yang kurang dari 5 tahun sebesar 25 orang (32,5\%), sedangkan responden yang memiliki masa kerja 5 tahun keatas sebesar 52 orang $(67,5 \%)$.

\section{Distribusi Responden Berdasarkan Jarak Monitor}

Kategori dari jarak monitor ada dua, yaitu sesuai dan tidak sesuai. Kategori sesuai apabila jarak monitor ke mata sekitar 46-61 cm (OSHA, 1997). Apabila tidak dalam rentang jarak tersebut maka dikategorikan tidak sesuai. Tabel 1 menggambarkan distribusi responden berdasarkan jarak monitor karyawan PT. Indonesia Power UP Semarang. Hasil penelitian yang dipaparkan pada Tabel 3 diketahui bahwa lebih banyak karyawan dengan jarak mata ke monitor yang telah sesuai dibandingkan dengan karyawan dengan jarak yang tidak sesuai.

Tabel 1. Distribusi Responden Berdasarkan Jarak Monitor di PT. Indonesia Power Up Semarang Tahun 2016

\begin{tabular}{lcc}
\hline Jarak Monitor & Frekuensi (n) & Persentase (\%) \\
\hline Sesuai & 60 & 77,9 \\
Tidak sesuai & 17 & 22,1 \\
\hline Jumlah & 77 & 100 \\
\hline
\end{tabular}

Tabel 2. Distribusi Responden Berdasarkan Durasi Penggunaan Komputer PT. Indonesia Power Up Semarang Tahun 2016

\begin{tabular}{lcc}
\hline $\begin{array}{c}\text { Durasi } \\
\text { Penggunaan } \\
\text { Komputer }\end{array}$ & Frekuensi (n) & $\begin{array}{c}\text { Persentase } \\
(\%)\end{array}$ \\
\hline$\leq 4$ jam & 32 & 42,6 \\
$>4$ jam & 45 & 58,4 \\
\hline Jumlah & 77 & 100 \\
\hline
\end{tabular}

\section{Distribusi Responden Berdasarkan Durasi Penggunaan Komputer}

Durasi penggunaan komputer memiliki dua kriteria yaitu kurang dari sama dengan 4 jam dan lebih dari 4 jam. Tabel 2 menggambarkan distribusi responden berdasarkan durasi penggunaan komputer yang sering dilakukan karyawan PT. Indonesia Power UP Semarang. Hasil penelitian yang dipaparkan pada Tabel 2 diketahui bahwa responden yang bekerja lebih dari 4 jam lebih banyak dibandingkan dengan responden yang bekerja kurang dari 4 jam.

\section{Distribusi Responden Berdasarkan Tampilan Layar Monitor}

Tampilan layar monitor memiliki dua kriteria yaitu baik dan buruk. Dikategorikan buruk apabila memenuhi syarat: tampilan gambar atau tulisan kabur atau buram, monitor berkedip, silau, serta font huruf, gambar, dan icon terlalu kecil. Apabila tidak memenuhi syarat seperti itu maka dikategorikan tampilan monitornya baik. Tabel 3 menggambarkan distribusi responden berdasarkan tampilan layar monitor karyawan PT. Indonesia Power UP Semarang. Hasil penelitian yang dipaparkan pada Tabel 3 diketahui bahwa responden yang memiliki tampilan baik lebih banyak

Tabel 3. Distribusi Responden Berdasarkan Tampilan Layar Monitor di PT. Indonesia Power Up Semarang Tahun 2016

\begin{tabular}{lcc}
\hline $\begin{array}{c}\text { Tampilan Layar } \\
\text { Monitor }\end{array}$ & Frekuensi (n) & Persentase (\%) \\
\hline Baik & 58 & 75,3 \\
Kurang baik & 19 & 24,7 \\
\hline Jumlah & 77 & 100 \\
\hline
\end{tabular}


Tabel 4. Distribusi Responden Berdasarkan Pencahayaan di PT. Indonesia Power Up Semarang Tahun 2016

\begin{tabular}{lcc}
\hline \multicolumn{1}{c}{ Pencahayaan } & Frekuensi (n) & Persentase (\%) \\
\hline Sesuai & 26 & 33,8 \\
Kurang sesuai & 51 & 66,2 \\
\hline Jumlah & 77 & 100 \\
\hline
\end{tabular}

dibandingkan dengan responden dengan tampilan yang kurang baik.

\section{Distribusi Responden Berdasarkan Pencahayaan}

Variabel intensitas pencahayaan dibagi menjadi dua kategori yaitu baik dan buruk. Intensitas pencahayaan dikatakan baik apabila telah memenuhi standar yaitu 300-500 lux, dan dikatakan buruk apabila intensitas di luar dari jangkauan tersebut. Tabel 4 menggambarkan distribusi responden berdasarkan pencahayaan di lokasi tempat kerja PT. Indonesia Power UP Semarang. Hasil penelitian yang dipaparkan pada Tabel 4 diketahui bahwa sebagian besar pekerja memiliki pencahayaan yang buruk atau tidak sesuai dengan standar.

\section{Gambaran Keluhan Kelelahan Mata}

Hasil penelitian yang digambarkan pada Tabel 5 dipaparkan bahwa sebagian besar responden mengeluhkan kelelahan mata ketika bekerja menggunakan komputer. Gambaran gejala keluhan kelelahan mata yang sering dirasakan oleh karyawan PT. Indonesia Power UP Semarang dapat dilihat pada Gambar 1.

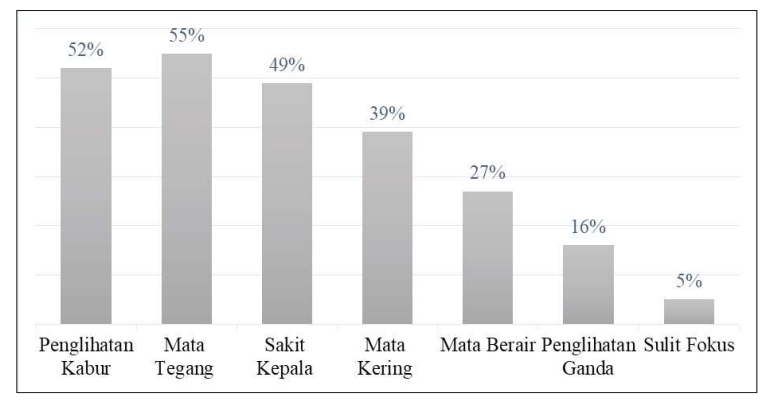

Gambar 1. Gejala Keluhan Kelelahan Mata yang Sering Dialami Pekerja di PT Indonesia Power Up Semarang Tahun 2016
Tabel 5. Distribusi Responden Berdasarkan Keluhan Kelelahan Mata di PT. Indonesia Power Up Semarang Tahun 2016

\begin{tabular}{lcc}
\hline $\begin{array}{c}\text { Keluhan } \\
\text { Kelelahan Mata }\end{array}$ & Frekuensi (n) & Persentase (\%) \\
\hline Ya & 62 & 80,5 \\
Tidak & 15 & 19,5 \\
\hline Jumlah & 77 & 100 \\
\hline
\end{tabular}

Berdasarkan tampilan gambar 1, dari ketujuh jenis gejala tersebut terdapat tiga jenis gejala yang memiliki persentase tertinggi dialami oleh karyawan PT. Indonesia Power UP Semarang yaitu mata tegang, penglihatan kabur, dan sakit kepala. Sedangkan gejala yang jarang sekali dikeluhkan oleh karyawan yaitu penglihatan ganda dan sulit fokus.

\section{Analisis Hubungan Jarak Monitor dengan Kelelahan Mata}

Hasil analisis hubungan antara jarak monitor dengan keluhan kelelahan mata pada Tabel 6, menunjukkan bahwa sebanyak 78,3\% karyawan dengan jarak yang sesuai merasakan kelelahan mata, sedangkan sebanyak $88,2 \%$ karyawan dengan jarak yang tidak sesuai merasakan kelelahan mata. Hasil uji statistik chi-square didapatkan nilai $P$-value $=0,499$. Nilai $P$-value lebih dari nilai $\alpha$, maka dapat disimpulkan bahwa antara jarak monitor dengan keluhan kelelahan mata tidak memiliki hubungan yang signifikan pada karyawan PT. Indonesia Power UP Semarang.

\section{Analisis Hubungan Durasi Penggunaan Komputer dengan Kelelahan Mata}

Hasil analisis hubungan antara durasi penggunaan komputer dengan keluhan kelelahan mata pada Tabel 6, diperoleh informasi bahwa sebanyak $93,8 \%$ pekerja dengan durasi penggunaan komputer kurang dari sama dengan 4 jam merasakan kelelahan mata. Sebanyak $71,1 \%$ pekerja dengan durasi penggunaan komputer lebih dari 4 jam merasakan kelelahan mata. Hasil uji statistik chi-square diperoleh nilai $P$-value $=0,018$. Nilai $P$-value kurang dari $\alpha$, maka dapat disimpulkan bahwa terdapat hubungan yang signifikan antara durasi penggunaan komputer dengan keluhan kelelahan mata pada Karyawan PT. Indonesia Power UP Semarang. 
Tabel 6. Hubungan Jarak Monitor, Durasi Penggunaan Komputer, Tampilan Layar Monitor, dan Pencahayaan dengan Kelelahan Mata di PT Indonesia Power Up Semarang Tahun 2016

\begin{tabular}{|c|c|c|c|c|c|c|c|c|c|}
\hline \multirow{3}{*}{ Variabel } & \multirow{3}{*}{ Kategori } & \multicolumn{4}{|c|}{ Kelelahan mata } & \multirow{2}{*}{\multicolumn{2}{|c|}{ Total }} & \multirow{3}{*}{$\alpha$} & \multirow{3}{*}{ P-value } \\
\hline & & \multicolumn{2}{|c|}{ Ya } & \multicolumn{2}{|c|}{ Tidak } & & & & \\
\hline & & $\mathbf{n}$ & $\%$ & $\mathbf{n}$ & $\%$ & $\mathbf{N}$ & $\%$ & & \\
\hline \multirow{2}{*}{ Jarak monitor } & Sesuai & 47 & 78,3 & 13 & 21,1 & 60 & 100 & \multirow{2}{*}{0,05} & \multirow{2}{*}{0,499} \\
\hline & Tidak sesuai & 15 & 88,2 & 2 & 11 & 17 & 100 & & \\
\hline \multirow{2}{*}{$\begin{array}{l}\text { Durasi } \\
\text { penggunaan } \\
\text { komputer }\end{array}$} & $\leq 4 \mathrm{jam}$ & 30 & 93,8 & 2 & 6,3 & 32 & 100 & \multirow{2}{*}{0,05} & \multirow{2}{*}{0,018} \\
\hline & $>4$ jam & 32 & 71,1 & 13 & 28,9 & 45 & 100 & & \\
\hline \multirow{2}{*}{ Tampilan monitor } & Buruk & 19 & 100 & 0 & 0 & 19 & 100 & \multirow{2}{*}{0,05} & \multirow{2}{*}{0,016} \\
\hline & Baik & 43 & 74,1 & 15 & 25,9 & 58 & 100 & & \\
\hline \multirow{2}{*}{ Pencahayaan } & Sesuai & 21 & 80,8 & 5 & 19,2 & 26 & 100 & \multirow{2}{*}{0,05} & \multirow{2}{*}{1,000} \\
\hline & Tidak sesuai & 41 & 80,4 & 10 & 19,6 & 51 & 100 & & \\
\hline
\end{tabular}

\section{Analisis Hubungan Tampilan Layar Monitor dengan Kelelahan Mata}

Hasil analisis hubungan antara tampilan layar monitor dengan keluhan kelelahan mata pada tabel 6, didapatkan bahwa sebanyak $100 \%$ responden dengan tampilan komputer buruk merasakan kelelahan mata, sedangkan responden dengan tampilan monitor yang sudah baik sebanyak $74,1 \%$ karyawan merasakan kelelahan mata. Hasil uji statistik chi-square didapatkan nilai $P$-value $=0,016$. Nilai $P$-value kurang dari nilai $\alpha$, maka dapat disimpulkan bahwa ada hubungan yang signifikan antara tampilan monitor dengan keluhan kelelahan mata pada karyawan PT. Indonesia Power UP Semarang.

\section{Analisis Hubungan Pencahayaan dengan Kelelahan Mata}

Hasil analisis hubungan antara pencahayaan dengan keluhan kelelahan mata yang dirasakan oleh karyawan seperti pada tabel 6 menunjukkan bahwa karyawan dengan pencahayaan yang baik sebesar 80,8\% mengalami kelelahan mata. Sebesar $80,4 \%$ karyawan dengan pencahayaan yang buruk mengalami kelelahan mata. Berdasarkan hasil uji statistik chi-square didapatkan $P$-value $=1,000$. Diperoleh nilai $P$-value lebih dari nilai $\alpha$, maka dapat ditarik kesimpulan bahwa tidak hubungan yang signifikan antara pencahayaan dengan keluhan kelelahan mata yang dirasakan oleh karyawan PT. Indonesia Power UP Semarang.

\section{PEMBAHASAN}

\section{Hubungan Jarak Monitor dengan Kelelahan Mata}

Salah satu faktor yang menentukan kenyamanan bekerja menggunakan komputer terutama saat memandang objek dalam jangka waktu yang cukup lama sesuai dengan kriteria pekerja kantoran adalah jarak mata dengan layar monitor komputer. Menurut Occupational Safety and Health Association (OSHA) (1997) jarak antara mata dengan layar monitor komputer yang baik yaitu 18-24 inch atau 46-61 cm, sedangkan jarak ideal yaitu 20 inch atau sekitar $50,80 \mathrm{~cm}$.

Analisis hubungan jarak monitor dengan keluhan kelelahan mata menunjukkan bahwa tidak ada hubungan antara jarak monitor dengan kelelahan mata. Hasil analisis ini sejalan dengan penelitian yang dilakukan oleh Sya'ban dan Riski (2014) serta Fadhillah (2013), bahwa penelitian mereka juga menyatakan tidak hanya hubungan antara jarak monitor dengan kelelahan mata. Penyebab tidak adanya hubungan ini mungkin dikarenakan faktor lainnya seperti pencahayaan yang kurang optimal.

Kelelahan mata bisa terjadi jika mata difokuskan pada objek dalam jangka waktu yang 
lama dengan jarak ke mata yang dekat sehingga otot mata harus bekerja lebih keras untuk memandang objek yang bergerak dalam jarak sangat dekat, khususnya apabila disertai dengan pencahayaan yang menyilaukan mata. Kondisi seperti ini menyebabkan mata harus beradaptasi dengan cara berakomodasi dalam jangka waktu yang lama sehingga terjadinya penurunan daya akomodasi mata (Roestijawati, 2007).

Upaya pencegahan yang dapat dilakukan untuk mengurangi keluhan kelelahan mata yaitu dengan memperhatikan jarak mata dengan layar monitor. Menurut Long dkk (2014) saat mata melihat benda dalam jarak dekat, maka mata akan dipaksakan untuk melakukan proses akomodasi dan konvergensi. Akomodasi adalah fase saat mata mengatur kefokusannya untuk melihat benda dari jarak tertentu sehingga benda tersebut terlihat jelas (focus), sedangkan konvergensi merupakan gerakan refleks mata guna menghindar dari munculnya penglihatan ganda (double vision). Oleh karena itu, jarak pandang mata yang semakin jauh berkemungkinan menyebabkan terjadinya iritasi mata karena proses konvergensi dan akomodasi mata yang berlebihan.

\section{Hubungan Durasi Penggunaan Komputer dengan Kelelahan Mata}

Undang-Undang No. 13 Tahun 2003 tentang Ketenagakerjaan mengatur terkait jam kerja bagi pekerja dengan standar 8 jam dalam sehari atau 40 jam dalam satu minggu (lima hari kerja). Bila dilihat sepintas jam kerja yang tinggi atau berlebihan tentu akan menguntungkan bagi perusahaan, karena akan menghasilkan produk atau jasa yang tinggi. Berbeda dengan kenyataan yang ada, karena jam kerja yang berlebihan akan membuat performa kerja karyawan menjadi menurun dan pekerja akan memiliki kecenderungan menimbulkan masalah lain seperti kelelahan, penyakit, dan kecelakaan kerja, dan berujung pada produktivitas yang menurun (Guyton dan Hall, 2014). Seseorang yang bekerja mengunakan komputer dalam jangka waktu yang lama didukung dengan jarak yang terlalu dekat juga memiliki risiko terkena kelelahan mata. Hal ini diperkuat dengan pernyataan Long dkk (2014) bahwa mata akan mencoba untuk memfokuskan pandangannya agar tetap berkonsentrasi ketika ia dihadapkan pada pekerjaan yang berulang-ulang atau terus-menerus guna mengurangi kesalahan.

Durasi penggunaan komputer yang optimum adalah tidak lebih dari 4 jam dalam sehari. Bila lebih dari 4 jam, maka mata cenderung lebih cepat mengalami refraksi. Oleh karena itu, untuk mengurangi cepatnya terjadinya refraksi mata ketika seorang pekerja bekerja menggunakan komputer lebih dari 4 jam sehari maka alangkah baiknya apabila melakukan istirahat mata lebih sering (Ilyas, 2005).

Berdasarkan analisis hubungan antara durasi penggunaan komputer dengan keluhan kelelahan mata diperoleh kesimpulan bahwa terdapat hubungan yang bermakna antara keduanya. Hasil ini diperkuat dengan penelitian sebelumnya yang telah dilakukan oleh Sya'ban dan Rizki (2014), yang menyatakan bahwa durasi berinteraksi dengan komputer berpengaruh terhadap keluhan kelelahan mata. Durasi penggunaan komputer berhubungan dengan keluhan kelelahan mata karena saat karyawan berinteraksi dengan komputer, maka otot mata akan dipaksa untuk bekerja secara terus menerus agar tetap fokus sehingga mengalami ketegangan otot dan menyebabkan kelelahan mata.

Menurut Anshel (2005), pencegahan yang dapat dilakukan untuk mengurangi keluhan kelelahan mata akibat durasi penggunaan komputer yang berlebihan dengan melakukan "3B" yaitu berkedip (blink), bernafas (breath), dan beristirahat (break). Saat keadaan normal mata akan berkedip 12-15 kali dalam satu menit, namun apabila sedang membaca, berfikir, dan sedang berkonsentrasi dengan pekerjaan, maka frekuensi berkedip akan berkurang. Frekuensi berkedip yang berkurang inilah yang menyebabkan kita mengeluhkan kelelahan mata. Mengedipkan mata sejenak maka akan membuat mata beristirahat dalam sesaat dan akan terjadi proses pembersihan mata serta proses pembasahan ulang pada mata sehingga mata tidak kering dan penglihatan akan jernih kembali. Apabila dalam keadaan stress dengan tuntutan tugas yang tinggi, maka pekerja cenderung menahan nafasnya saat bekerja. Dalam keadaan inilah yang akan mengakibatkan otot-otot tubuh termasuk otot mata menjadi tegang sehingga perlu menarik nafas dengan teratur dan benar (rileks). Tuntutan tugas yang berlebihan juga dapat menimbulkan keluhan kelelahan mata karena saat bekerja perlu konsentrasi yang tinggi sehingga perlu dilakukan istirahat singkat dengan teratur.

Menurut OSHA (1997), istirahat yang baik saat penggunaan komputer yaitu dengan beristirahat selama 5 menit setelah berinteraksi dengan komputer selama 30 menit atau beristirahat selama 10 menit setelah bekerja 1 jam. Nourmayanti (2010) menyatakan bahwa pengguna komputer seharusnya 
sering-sering melakukan istirahat singkat namun teratur, sehingga karyawan tidak terus menerus berhadapan dengan komputer.

Aturan istirahat mata yang sering dipakai untuk bekerja di depan komputer ialah aturan 20-20-20, artinya setelah bekerja menggunakan komputer selama 20 menit, sebaiknya mengalihkan pandangan dari layar monitor dengan melihat benda yang berjarak 20 kaki atau sekitar 6 meter dari kita selama 20 detik.

\section{Hubungan Tampilan Layar Monitor dengan Kelelahan Mata}

Salah satu faktor yang menyebabkan keluhan kelelahan mata pada pengguna komputer adalah pengaturan kekontrasan pada tampilan layar monitor. Secara sederhana kontras layar monitor dapat diartikan sebagai perbedaan ketajaman warna karakter (huruf) dengan warna latar belakang (background) pada layar monitor (Priliandita, 2015). Pengaturan kontras pada layar monitor yang tidak tepat akan memperbesar peluang risiko terjadinya keluhan kelelahan mata pada penggunanya. Tingkat kontras yang paling ideal yaitu apabila warna karakter (huruf) lebih gelap sedangkan warna latar belakang lebih terang (dark letters on a light background). Misalnya huruf yang berwarna hitam sedangkan background berwarna putih. Tampilan seperti inilah yang dirasa paling nyaman bagi mata saat menggunakan komputer dalam jangka waktu yang lama (Ilyas, 2005).

Berdasarkan analisis hubungan, diperoleh informasi bahwa tampilan layar monitor memiliki hubungan yang bermakna dengan kelelahan mata. Penelitian ini selaras dengan penelitian yang dilakukan oleh Ziefle dalam Setiawan (2012), yang menuturkan bahwa salah satu dari tiga hal utama yang berhubungan dengan keluhan kelelahan mata adalah kualitas visual display terminal (VDT) seperti berkedip, resolusi, dan kekontrasan.

Tampilan monitor harus diatur sedemikian rupa sehingga nyaman untuk digunakan. Apabila ada tampilan yang mengganggu seperti terlalu suram, tampilan atau gambar kabur, monitor berkedip-kedip, silau, dan terlalu kecil font huruf gambar dan icon, serta sulit untuk dibaca, agar segera ditanggulangi dan tidak dibiarkan berlarut-larut (Setiawan, 2012).

Upaya lain untuk mengurangi keluhan kelelahan mata yaitu dengan cara meletakkan layar monitor pada tempat yang tidak menimbulkan pantulan cahaya dari sumber lain seperti cahaya dari jendela, lampu yang bisa membuat mata silau. Pemasangan kaca pelindung pada layar monitor (screen filter) juga diperlukan untuk mengurangi kesilauan maupun radiasi komputer. Mengatur dominasi warna pada background juga perlu dilakukan, seperti mengubah warna background menjadi hijau dengan warna huruf yang kontras sehingga tulisan masih bisa terbaca. Ukuran font yang ideal (standar) yang biasa digunakan dalam berkomputer adalah 12 pt. Hindari penggunaan font yang terlalu kecil dari standard ini. Apabila terpaksa menggunakan font yang lebih kecil maka dapat diatasi dengan memperbesar (zoom) tampilan layar komputer sehingga mata tidak cepat lelah.

\section{Hubungan Pencahayaan dengan Kelelahan Mata}

Pencahayaan yang baik menurut Suma'mur (2013) adalah pencahayaan yang memungkinkan pekerja dapat melihat dengan mudah objek-objek di sekitarnya secara jelas tanpa dibarengi upaya-upaya yang tidak perlu. Pencahayaan yang diatur secara baik dan cukup akan membantu membuat suasana lingkungan kerja menjadi menyenangkan dan nyaman sehingga dapat memelihara semangat kerja para karyawan serta meningkatkan produktivitas. Setiap pekerjaan memiliki tingkat intensitas pencahayaan yang berbeda-beda, bergantung pada jenis dan sifat pekerjaannya. Apabila intensitas pencahayaan kurang maka dapat mengakibatkan gangguan visibilitas dan eyestrain, sedangkan apabila intensitas pencahayaan yang berlebih akan menimbulkan gangguan visibility, glare, eyestrain, glare, reflections, dan excessive shadows (Tarwaka, 2011). Menurut Keputusan Menteri Kesehatan No. 1405 Tahun 2002 tentang Persyaratan Lingkungan Kerja dan Industri, intensitas pencahayaan minimal untuk bekerja adalah 100 lux. Akan tetapi berbeda dengan standard pencahayaan untuk ruangan perkantoran administrasi dan ruang kerja yang menggunakan komputer yaitu sebesar 300 lux.

Hasil penelitian diketahui bahwa pencahayaan tidak memiliki hubungan yang dengan kelelahan mata. PT. Indonesia Power UP Semarang memiliki pencahayaan yang kurang baik. Meskipun begitu dalam penelitian ini ditemukan bahwa antara karyawan yang memiliki pencahayaan yang baik maupun kurang, hampir semuanya mengeluhkan kelelahan mata. Hasil analisis hubungan ini berbeda dengan teori yang ada. Perbedaan ini disebabkan karena ada faktor lain di lingkungan kerja yang juga menjadi pemicu munculnya keluhan kelelahan 
mata seperti tuntutan tugas yang berbeda tiap individu sehingga berat beban kerja karyawan berbeda satu dengan yang lain, artinya beban kerja tiap karyawan tidak bisa disamaratakan. Selain itu, kondisi lingkungan seperti temperatur dan Indoor Air Quality (IAQ) yang juga mencakup bahan kimia di udara juga mempengaruhi kecepatan timbulnya keluhan kelelahan mata (Setiawan, 2012).

Tidak ditemukan hubungan antara pencahayaan dengan keluhan kelelahan mata, tetapi penulis merasa perlu perbaikan intensitas pencahayaan karena pencahayaan di tempat kerja masih ada yang tidak sesuai dengan standar, baik pencahayaan yang kurang maupun berlebihan. Untuk pencahayaan yang berlebihan akibat tambahan cahaya dari luar kantor, hal itu dapat ditanggulangi dengan menutup tirai jendela ruangan tersebut. Penggantian lampu yang rusak ataupun telah mati harus segera dilakukan sesuai dengan ketentuan yang diberlakukan di PT. Indonesia Power UP Semarang yaitu pengecekan sebulan sekali atau ketika mendapat laporan dari pekerja di ruangan yang bersangkutan bahwa terdapat lampu di ruangan mereka yang rusak ataupun mati. Untuk itu peranan pekerja juga diperlukan dalam memantau kondisi lampu di ruangan. Pembersihan dan pemeliharaan lampu serta luminaires perlu dilakukan minimal 6 bulan sekali.

Saran yang dianjurkan oleh Tarwaka (2011) untuk mengendalikan keluhan kelelahan mata di tempat kerja yaitu dengan memodifikasi sistem pencahayaan yang sudah ada serta perlu dilakukan modifikasi pekerjaan. Aplikasi modifikasi pencahayaan seperti halnya menaikkan atau menurunkan letak lampu berdasarkan letak objek kerja, mengganti jenis lampu yang lebih sesuai (Neon, dll), merubah posisi lampu, mengurangi atau menambah jumlah lampu, mengganti tudung lampu dan mengganti warna lampu. Contoh modifikasi pekerjaan misalnya membawa pekerjaan lebih dekat ke mata sehingga benda dapat dilihat dengan jelas dan merubah posisi kerja untuk menghindari bayangbayang sehingga tidak menimbulkan pantulan cahaya yang dapat menyilaukan mata.

\section{SIMPULAN}

Kesimpulan dalam penelitian ini adalah variabel yang memiliki hubungan dengan keluhan kelelahan mata pada pekerja PT. Indonesia Power UP Semarang yaitu durasi penggunaan monitor dan tampilan layar monitor, sedangkan yang tidak memiliki hubungan dengan keluhan kelelahan mata yaitu jarak monitor dan pencahayaan.

\section{DAFTAR PUSTAKA}

Anshel, J., 2005. Visual Ergonomic Handbook. [e-book] Boca Raton: CRC Press. Tersedia di: http://www.ssu.ac.ir/cms/fileadmin/user upload/Moavenatha/MBehdashti/TebKar/PDFs/ VISUAL_ergonomic_handbook.pdf [7 April 2017].

Ariyanti., 2006. Teknik Keselamatan dan Kesehatan Kerja Industri. Yogyakarta: Graha Ilmu.

Budiono S., Jusuf., Pusparini, A. 2008. Bunga Rampai Hiperkes \& KK. Cetakan III, Semarang: Badan Penerbit Universitas Diponegoro.

Fadhillah, SL., 2013. Faktor-Faktor yang Berhubungan dengan Keluhan Kelelahan Mata pada Pengguna Komputer di Accounting Grup PT. Bank X, Jakarta. Skripsi. Jakarta: Fakultas Kedokteran dan Ilmu Kesehatan UIN Syarif Hidayatullah.

Guyton, Hall, JE., 2014. Buku Ajar Fisiologi Kedokteran, Diterjemahkan oleh Adji Dharma, Jakarta: EGC Buku Kedokteran.

Ilyas, S., 2005. Penuntun Ilmu Penyakit Mata. Jakarta: Balai Penerbit FKUI.

Keputusan Menteri Kesehatan Republik Indonesia No. 1405 Tahun 2002 Tentang Persyaratan Kesehatan Lingkungan Kerja Perkantoran dan Industri. Jakarta: Kementerian Kesehatan.

Long, J., Rosenfield, M., Helland, M., Anshel, J. 2014. Visual Ergonomics Standards for Contemporary Office Environments, Ergonomics Australia, 10:1. Tersedia di: https://www.ergonomics.org. $\mathrm{au} /$ documents/item/203 [diakses tanggal 7 April 2017].

Nourmayanti, D. 2010. Faktor-Faktor yang Berhubungan dengan Keluhan Kelelahan Mata pada Pekerja Pengguna Komputer di Corporate Customer Care Center (C4) PT Telekomunikasi Indonesia, Tbk Tahun 2009. Skripsi. Jakarta: Fakultas Kedokteran dan Ilmu Kesehatan. Universitas Islam Negeri (UIN) Syarif Hidayatullah,

OSHA., 1997. Working Safety with Video Display Terminal a Dozen Things You Should Know about Eyestrain. Tersedia dari: http://www.osha.gov. (diakses tanggal 20 Maret 2016). 
Pheasant, S., 2005. Body space: Anthropometry, Ergonomics and the Design of work: third edition. London: Taylor and Francis.

Priliandita, NT., 2015. Analisis Faktor yang Berhubungan dengan Keluhan Computer Vision Syndrome pada Operator Komputer Warung Internet di Kelurahan Sumbersari Kabupaten Jember. Skripsi. Jember: Universitas Jember.

Roestijawati, N., 2007. Hubungan Penggunaan Visual Display Terminal (VDT), Faktor Pekerja dan Lingkungan Kerja dengan Sindrome Dry Eye. Jurnal Kedokteran YARSI, vol. 13, no. 2: 205-217. Tersedia dari: http://isjd.pdii.lipi.go.id/ admin/jurnal/1320520521708541159. diakses tanggal 2 Oktober 2016.

Santoso, FF., 2011. Hubungan Pencahayaan dan Karakteristik Pekerja dengan Keluhan Subjektif Keluhan Kelelahan Mata pada Operator Komputer TELE ACCOUNT Management di PT. Telkom Regional 2 Surabaya. Skripsi. Surabaya: Universitas Airlangga.

Santoso, I., 2009. Interaksi Manusia dan Komputer. Edisi 2. Yogyakarta: ANDI.

Setiawan, I., 2012. Analisis Hubungan Faktor Karakteristik Pekerja, Durasi Kerja, Alat Kerja, dan Tingkat Pencahayaan dengan Keluhan
Subjektif Keluhan Kelelahan Mata Pada Pengguna Komputer di PT. Surveyor Indonesia Tahun 2012. Skripsi. Depok: Fakultas Kesehatan Masyarakat. Universitas Indonesia.

Suma'mur, PK., 2013. Higiene Perusahaan dan Kesehatan Kerja (HIPERKES). Jakarta: Sagung Seto.

Supriati, F., 2012, Faktor-Faktor yang Berkaitan dengan Keluhan Kelelahan Mata Pada Karyawan Bagian Administrasi di PT. Indonesia Power UBP Semarang, Jurnal Kesehatan Masyarakat, [e-journal] 1(2): pp.720-730. Tersedia di: http:// ejournals1.undip.ac.id.index.php/jkm [diakses tanggal 25 Januari 2016].

Sya'ban, AR., Riski, IMR., 2014. Faktor-Faktor yang Berhubungan dengan Gejala Keluhan Kelelahan Mata (Astenopia) Pada Karyawan Pengguna Komputer PT. Grapari Telkomsel kota Kendari, Sembistek 2014 ibi darmajaya, 2407-6171: pp.754-768.

Tarwaka, 2011. Ergonomi untuk Keselamatan, Kesehatan Kerja dan Produktivitas. Surakarta: UNIBA Press.

Undang-Undang Republik Indonesia No. 13 Tahun 2003 tentang Ketenagakerjaan. Jakarta: Kementerian Ketenagakerjaan dan Transmigrasi. 